\title{
Marriage and Social Identity in The Return of the Native
}

\author{
Keshavarz, M. $^{1}$ and Ghasemi, . $^{2}$ \\ ${ }_{1,2}$ English Literature Department of Foreign Languages and Linguistics, Faculty of Humanities, Shiraz University, Shiraz, \\ IRAN.
}

\begin{abstract}
The Return of the Native presents a world in which "doing means marrying". Thomas Hardy shows how the dominant discourse of the Victorian society defines an individual's whole life through the conformity to the social code of marriage. This paper clarifies how Hardy's satirical tone implicitly reflects the voice of the minority, which is not able or eager to follow this conformity code of the majority. Through a detailed analysis of the significance of marriage in defining one's social identity, family relations, economic ambitions, and individual ideals, the paper focuses on a hermaphrodite character who cannot adapt to the majority's code because of his physical condition. Such an individual, as the paper presents, is marginalized by the majority and suffers from problems that might lead to psychological disorders. It is Hardy's implicit satirical tone, which encourages the readers to change their mental set about the role of marriage in defining one's identity.
\end{abstract}

Key words: Marriage, Thomas Hardy, marginality, onformity, hermaphrodite, double personality, satirical tone.

\section{INTRODUCTION}

In her introduction to The Return of the Native Margaret R.Higonnet opens a section under the title of Hardy's Modernity. In this introductory part she states that The Return of the Native moves Eustacia's marriage and death from their normal position at the close of the novel to the center. She also adds, "Like George Eliot in Middlemarch, Hardy deals with marriage "as a continuing, lived process".

McHale (1993) believes, "The state of a fictional world is a construct, just as the characters and objects that occupy it are, or the actions that unfold within it. Typically, in realist and modern writing, this spatial construct is organized around a perceiving subject, either a character or the viewing position adopted by a disembodied narrator" (p. 45).

The case of The Return of the Native is that of a realist, modern novel in which the perceiving subject is a disembodied narrator. The constructed world of this narrator is founded upon the concept of marriage. In fact, The Return of the Native can be considered as a sort of treatise on marriage.

There are so many pages all through the novel in which marriage is a direct or an indirect subject matter. It is also worthy to note that the existence of marriage provides lots of opportunities in which people's ideas, ideals, motivations, and apprehensions about marriage are analyzed.

The tone of the disembodied narrator in the presentation of the major theme of the novel is best understood if Bakhtin's definition of tone is applied to the whole novel. According to Bakhtin, tone or "intonation," is "oriented in two directions: with respect to the listener as ally or witness and with respect to the object of the utterance as the third, living participant whom the intonation scolds or caresses, denigrates or magnifies" (as cited in Abrams, 1999, p. 218).

Through a serious-satirical tone, Hardy tries to exert an enlightening approach on the concept of marriage which is "the object of the utterance" in The Return of the Native. Besides, in this novel marriage becomes a means through which social mobility, individual ambitions, class distinctions, family relations, social conventions, and some other concepts are portrayed.

That marriage is one of Hardy's obsessions in his novels is not something unknown to the readers or the critics. However, what makes The Return of the Native something unique among the other novels with the same "object of the utterance" is Hardy's (2008) poignant tone in depicting the situation of a minority group that is not capable of fulfilling the social expectations with regard to marriage: 
Eustacia had got beyond the vision of some marriage of inexpressible glory; yet, though her emotions were in full vigor, she cared for no meaner union ... In a world where doing means marrying and the common wealth is one of hearts and hands ... (pp. 70-71).

It is already clear that "in a world where doing means marrying" the vulnerable are the ones who are not willing to or able to marry. It is here that lies the uniqueness of The Return of the Native. In this novel getting married is presented as a form of social conformity within the frame of the dominant discourse. Various fields of the individual's life are defined through marriage.

\section{MARRIAGE AND SOCIAL IDENTITY}

As the novel opens, it is already shown that one's social identity and existence are recognized by the individual's marital status. In other words, individuals are registered to the society's level of consciousness through marriage and its implications. In the first pages of the novel while the characters are introduced to the reader, we encounter an old man asking a young one about a person who is moaning in the young one's cart:

"... perhaps she is your wife?"

"My wife" said the other bitterly. "She is above mating with such as I." (p. 15)

Moreover, in introducing Mrs. Yeobright and her behavior, Hardy says, "The explanation lay in the fact that though her husband had been a small farmer she herself was a curate's daughter who had once dreamt of doing better things." (p. 35)

Thomasian's speech provides us with another example of the vital presence of marriage as "the object of utterance" in the novel:

"O Damon, ... Here am I, asking you to marry me; when by rights you ought to be on your knees imploring me, your cruel mistress, not to refuse you, and saying it would break your heart if I did. I used to think it would be pretty and sweet like that; but how different!"

"Yes: real life is never all like that." (p. 46)

The next instance is about Eustacia's grandfather's opinion about his own daughter's marriage: "The marriage was scarcely in accord with the old man's wishes, for the bandmaster's pockets [Eustacia's father] were as light as his occupation.” (p. 68)

In her letter to Diggory Venn, Thomasian Yeobright states:
"I cannot, Diggory, marry you ... There are so many reasons why we cannot be married ... Another reason is my aunt. She would not, I know, agree to it, even if I wished to have you ... She will want me to look a little higher than a small dairy-farmer, and marry a professional man" (p. 79).

In the rejection of Diggory's proposal, Thomasian, in the letter, adds that the reason with her own personal self for not letting him court her is that "she does not feel the things a woman ought to feel when who consents to walk with a man with the meaning of being his wife. "It is clear that Thomasian's ideal marriage is the one in which she, as a woman, ought to feel something towards the man she is going to marry but in the second book of the novel, chapter eight, it is again Thomasian who says, "I am a practical woman now. I don't believe in hearts at all. I would marry him [Mr. Wildeve] under any circumstances" (p. 153).

It is obvious that Thomasian's ideas or/and ideals about marriage have been greatly challenged and changed by the actual circumstances of her situation. These ideals/ideas are still subject to further changes and challenges as the novel itself is going to present.

That marriage is a significant social theme occupying the novel's pages and the characters' mentality is confirmed when you consider Clym Yeobright's mind. He tells his mother about his own motivations in marrying Eustacia: If I take a school, an educated woman would be invaluable as a help to me" (p. 189). Mrs. Yeobright who is annoyed by Clym's choice tells Thomasian, "Some widows can guard against the wounds their children give them by turning their hearts to another husband, and beginning life again. But I always was a poor, weak one-idea'd creature ..." (p. 209) To this statement Thomasian responds, "It was more noble in you that you did not" and Mrs. Yeobright says, "The more noble, the less wise" (p. 189).

Clearly enough, marriage presents itself here and there in the novel to introduce, to affirm, or to reject the individual's expectations. That is, getting married influences one's social identity, and it sometimes reveals "the vanity of human wishes". In the fourth book, chapter one, you read, "Now Eustacia's dream had always been that, once married to Clym, she would have the power of inducing him to return to Paris" (p. 233).

In the same part of the novel it is mentioned that "Yeobright was as firm in the contrary intention as if 
the tendency of marriage were rather to develop the fantasies of young philanthropy than to sweep them away" (p. 234). This contrast in the couple's point of view and the tragic consequences of the diversity can be plainly observed in Eustacia's comment on their own marriage: "Two wasted lives-his, and mine" (p. 249).

The impartiality with which Eustacia judges their own marriage is horribly appealing. She also adds that "The marriage is no misfortune ... It is simply the accident which has happened since that has been the cause of my ruin. I have certainly got thistles for figs in a worldly sense, but how could I tell what time would bring forth?" (p. 272).

The unpredictability of life also has its own influence on one's marriage and it is the experience of Eustacia, which proves this notion. She says, "All persons of refinement have been scared away from me since I sank into the mire of marriage." (p. 318) This also shows how terribly her expectations and her real achievements in marriage have been different from each other. The experiences that Eustacia had gained through marriage are candidly and realistically expressed by her. When Wildeve shows her eagerness to help her, Eustacia says, "We are each married to another person... and assistance from you, however correct, would have an evil sound" (p. 329).

The examples above confirm the notion that marriage has its own impacts on one's life. That is, the individual's social contacts and relations are defined in different ways when $\mathrm{s} / \mathrm{he}$ is married. The forming process of the definitions, however, is not always fair or justifiable; it is only a married person who can feel the imposed social or individual limitations on his/her life which are the inevitable consequences of those definitions.

It was already clarified that marriage influences family relations as well. Thomas Hardy directly emphasizes on this fact by stating, "There was a little more reticence now than formerly in Thomasian's manner towards her cousin [Clym]. It is the effect of marriage to engender in several directions some of the reserve it annihilates in one" (p. 240). It is also important to consider Mrs. Yeobright's idea that, "Both she [Thomasian] and my son [Clym] disobeyed me in marrying; therefore, I have no interest in their households. Their troubles are of their own making" (p. 263).

According to the above examples, family and blood relations are affected by one's marriage; however, this is not the only realm in which marriage operates. In other words, those who have no relations to an individual might be affected by his/her marriage. It is a fact to which Eustacia refers:

If you [Clym] had never returned to your native place, what a blessing it would have been for you....It has altered the destinies of------

"Three people"

"Five, Eustacia thought; but she kept that in" (p. 265).

All the above mentioned extracts and comments confirm the notion that the theme of marriage constitutes an integral "continuing lived process" in The Return of the Native. This theme is so vital that the world of the novel is established upon it. The existence of this "continuing lived process", as we have already seen, is referred to by Margaret R. Higonnet. However, the other aspect of modernity which is not observed by Higonnet is that through constructing the whole world of the novel on the object of "marriage" Hardy indirectly poses the question of nonconformity. In other words, he presents a minority who willingly (in the case of Eustacia) or unwillingly (in Christian's case) may not readily adapt themselves to the dominant discourse of the Victorian society with regard to marriage.

The main purpose of this paper is to show Hardy's satirical concern about the nonconformist's life in a society which defines conformity through marriage. In fact marriage and life are treated as rather synonymous concepts in the world of the novel. The Grandfer says, "In common conscience every man ought either to marry, or go for a soldier. Tis a scandal to the nation to do neither one or the other. I did both, thank God. Neither to raise men nor to lay'em lowthat shows a poor do-nothing spirit indeed" (p. 382).

To challenge the dominant discourse that "in common conscience every man ought to marry or go for a soldier", Thomas Hardy introduces a character, called Christian, who confesses, "I never had the nerve to stand fire ... But as to marriage, I own I've asked here and there, though 'it hout much fruit from it' (p. 382).

This peculiar character is introduced by Hardy from the very beginning of the novel. In the first chapter a group of speakers are discussing Wildeve and Thomasian's impending marriage. Some of them consider this marriage while some others are against it. As the case is commented upon by different characters, Humphrey asks, "Did'st ever know a man, neighbor, that no woman at all would marry? (p. 27) Many of the participants answer in negative; however, Timothy Fairway says, "I did know of such a man. But only once, mind." He also adds that the 
person is not known in the area. While the conversation goes on, a boy notices that Christian Cantle's teeth are chattering. They ask if he feels cold and he says no. They inquire about the reason of his reaction and he asserts, "I am the man."

"What man?"

"The man no man will marry. Yes I be he; and it makes me afeaared ... Do you think 'twill hurt me? I shall always say I don't care, and swear to it, though I do care all the while" (p. 28).

To this confession Mr. Fairway reflects: I didn't mean you at all. There is another, then! Why did you reveal your misfortune Christian? (p. 28).

"There is another in the country" confirms the idea that such characters are not unique in the marriagebased society of The Return of the Native. That is, "the man whom no woman will marry" does present a minority. In other words, there is someone else in the area, according to Mr. Fairway, whose "misfortune" is the same as that of Christian. It is the first time, however, that the taken for granted notion of this Victorian nuptial ideology is challenged by a different possibility.

It is Hardy, the modern novelist who provides a fictional character through whom his readers are faced with an individual who greatly suffers from his situation as the "other". The existence of this character is marginalized and ignored by the majority. Christian is the representative of the "other" and it is through him that the world of the novel experiences another possibility of human life; a possibility in which doing may not necessarily mean marrying.

Fairway says "Why did you reveal your misfortune?" and Christian answers, "It was to be if't was, I suppose. I can't help it can I?' Fairway follows the conversation stating, "No: that's true. But this is a melancholy thing, and my blood ran cold when you spoke, for I felt there were two poor fellows where I had thought only one. Tis a sad thing for you, Christian. How'st know the women won" thae thee? "I've asked 'em"

"Sure I should never have thought you had the face. Well, and what did the last one say to ye? Nothing that can't be got over perhaps after all?

"Get out of my sight, you slack-twisted slim looking fool,' was the woman's words to me."

"Not encouraging, I own" said Fairway. "Get out of my sight, you slack-twisted slim-looking fool, 'is rather a hard way of saying No" (p. 28).

Through the repetition of the exact words of the unknown woman, Thomas Hardy satirically reveals and rebukes the social behavior of his own society while dealing with the "others". According to Robyn R. Warhol, "In depicting the "real world", the realist novelist often tried to make genuine changes in that world by inspiring readers to transform their own notions of their moral and social selves, their own sense of responsibility to others." (xii) Moreover, Quintero believes that, "satirists ... encourage ... our need for ... shaking us from our complacency and indifference." (p. 4). He also states, "The satirist, in seeking a reformation of thought expects readers to engage the satire by their reasoning, moral values, and tastes to the subject" (p.5).

Therefore, Hardy, the realist satiric novelist brings the question of the nonconformity to the level the consciousness of his readers. In other words, he makes the readers confront the situation of an individual who is either unwilling or unable to marry. The major butt of Hardy's satire is the society that neither recognizes these nonconformists nor sympathizes with them. Through creating such a character, Hardy expects and seeks a reformation of thought in his readers. He inspires that "sense of responsibility to others" which is mentioned by Warhol (1989) and makes an effort to "shake us from our indifference" which Quintero ascribes to the satirist.

Christian's "misfortune" is interpreted by the superstitions of his companions. They refer to the night in which Christian was born. The old saying, "No moon, No man", Fairway believes, "Tis one of the truest sayings ever spit out. The boy never comes to anything that is born at new moon"'(p. 29).

The explanatory notes of the novel suggest that the saying, "No moon, No man" means that a man born under such conditions (born in the interval between an old moon and the first appearance of a new one) refers to a hermaphrodite (p. 395). Introducing of a hermaphrodite character to the world of fiction has its own background. According to Williams (2004)-, "Lamartine's work ... does ... bear the impress of a fascination among French writers of the period with the figure of the ambiguously gendered creature." ( $p$. xiv) This paper emphasizes that the registration of "an ambiguously gendered" character in the marriagebased world of The Return of the Native presents that aspect of modernity in Thomas Hardy's art which has not been mentioned by Higonnet.

This paper appreciates and analyzes the presence of such a character because his existence provides us with an opportunity to re-evaluate our own conceptions about human conduct. . In other words, in a world that the dominant discourse shapes, judges, and interprets one's life by one's marital situation or 
prospective marriage, a hermaphrodite character like Christian, whose physical condition does not allow him to marry, is treated not as an ordinary human being but as "a slight, slacked-twisted slim looking fool". Such a character has always been suppressed by the social conventions of the Victorian era.

As the novel shows this "queer" character is humiliated based on the physical condition over which he himself has had no control. The way the society treats the "hermaphrodite" is "not encouraging", Hardy observes. Moreover, the very name of this character, "Christian" conveys the fate he has to bear in the Victorian society. According to Babb (1986), "Hardy does in effect evaluate many of his characters by the names he chooses for them." (p. 373) Therefore, this paper states that the marriagebased ideology of the Victorian society, which is depicted by the novel, would crucify this character to consolidate its own marital code. The idea that a hermaphrodite character is subject to be crucified is also mentioned by Williams (2004) in the introduction he has on The Hermaphrodite by Julia Ward Howe:

Howe's protagonist ... is the embodiment of a cross...He falls ill and in his delirium has a vision in which a woman and a man are fighting for possession of his body. He feels his bowels torn asunder by his love for both, a pain that finds expression in an image of crucifixion. A voice ... tells him, "A cross is not formed otherwise than of two loves or two desires which Cross each other or conflict" (p. xxxv).

Through introducing "Christian" to the nuptial world of his novel, Hardy the satirist offers his marginalized character an opportunity of self-expression. He also provides his readers and fictional characters with a new human condition, which has never been recognized by them. Master Fairway sympathizes with Christian in this way "You have to lie alone all your life and it is not to married couples but to single sleepers that a ghost shows himself when "a do come" (p. 29).

The implied satirical tone criticizes the outlook of the society about marriage. The idea that "ghosts appear to the single sleepers, not to the married couples" reinforces Hardy's critical stand against the discourse that produces nuptial superstitions through which the code of marriage in the discourse of the society is reinforced.

"Discourse is not just a way of speaking or writing, but the whole 'mental set' and ideology which encloses the thinking of all members of a given society" (Barry, 2009, p. 154). Therefore, the butt of Hardy's satirical tone is the whole Victorian mindset by which matrimony is depicted as an undoubted blissful state of life.

In a society that registers an individual's identity and existence through marriage, a hermaphrodite individual is deprived of his/her social self. S/he becomes "the other", "the marginalized" or the "invisible" minority whose existence is ignored. Such a character suffers from various pressures, which bring about psychosomatic consequences. Christian says, "D'yethink it will hurt me? I shall always say I don't care, and swear to it, though I do care all the while" (Hardy, 2008, p. 28).

"Gender and sexuality have been identified by modern and postmodern theorists as key determinants of subjectivity" (Mansfield, 2000, p. 105). As a result, the hermaphrodite character of the novel is incapable of achieving an integrated subjectivity and this is shown by the two "selves" he presents: the self or the subject who cares the damage, and the one that swears he does not.

Christian's situation reminds us of what Schweik (1986) calls, "The contrast between lives lived psychologically and physically apart, in greatly different situations and equally different emotional atmospheres" (p. 440). Though the double "selves" are created by the bilateral sexuality or "the ambiguously gendered" situation of the character, there is no doubt the society has its own role in creating the double subjectivity of the character. In other words, if the character could express his own peculiar condition, he would not swear that he did not care about his lonesome suffering. He has to pretend that he does not care while he does. The inevitable outcome of a long life pretension produces a human character whose situation confirms what Gautier's protagonist [Madelaine] states: It often happens that the sex of the soul does not at all correspond with that of the body, and this is a contradiction which cannot fail to produce great disorder"(Williams, 2004, p. $\mathrm{xvi)}$.

From the late decades of the twentieth-century literary and cultural theories have tried through all their "isms" to present and discuss the problems of marginality, repression, and suppression o the minorities. However, it is interesting that Thomas Hardy creates a fictional character to reveal his own anxieties, which are shared by the literary and cultural concerns of our time. That is to say, Hardy makes an effort to inform his readers of the emotional and psychological sufferings of an individual who is not 
able to conform to the supposedly miraculous nuptial prescription of the Victorian mindset.

The major purpose of this paper has been to show how Hardy constructs the whole world of his novel on the concept of marriage, then through an implicit deconstruction of such a world he invites us to see the other possible world in which "doing" does not necessarily "mean marrying". This new world belongs to those who are classified as "the others" and they have been invisible to the Victorians.

\section{CONCLUSION}

The conclusion we have come to is that by creating a "queer" character, Thomas Hardy has tried to remind his readers of the presence of the minority whose existence has been neglected or denied by the majority. In his treatment of the "real world" of the Victorian society, the satirical novelist fulfills Quintero's (2007) idea that "The satirist, either explicitly or implicitly, tries to sway us toward an ideal alternative, toward a condition of what the satirist believes should be. It is assumed that the artist has our best interest at heart and seeks improvement or reformation" (p. 3).

\section{REFERENCES}

Abrams, M.H. (1999). A Glossary of literary terms ( $7^{\text {th }}$ ed.). Boston MA: Heinle \& Heinle.
Babb, H. (1986). Setting and theme in far from the madding crowd. In Robert C. Schweik (Ed.), Far from the madding crowd: An authoritative text, background, criticism (pp. 370-381). New York: W. W. Norton \& Company.

Barry, P. (2009). Beginning theory: An introduction to literary and cultural theory ( $3^{\text {rd }}$ ed.). Manchester: Manchester UP.

Hardy, T. (2008). The return of the native. Oxford: Oxford UP.

Mansfield, N. (2000). Subjectivity: The theories of self from Freud to Haraway. Sydney: Allen \& Unwin.

McHale, B. (1993). Postmodernist fiction. London: Routledge.

Quintero, R. (2007). Introduction: Understanding satire. In R. Quintero (Ed.), A companion to satire: Ancient and modern (pp. 3-11). Malden, MA: Blackwell Publishing Ltd.

Schweik, R. C. (1986). Hardy's shifting narrative modes. In R.C. Schweik (Ed.), Far from the madding crowd: An authoritative text, backgrounds, criticism. New York: W. W. Norton \& Company.

Warhol, R. R. (1989). Gendered interventions: Narrative discourse in the Victorian novel. New Brunswick: Rutgers UP.

Williams, G. (Ed.). (2004). Introduction. In J. W. Howe, The hermaphrodite (pp. ix-xliv). London: University of Nebraska Press. 